\title{
MOTIVASI BELAJAR LANSIA DALAM MENGIKUTI PENGAJIAN RUTIN AHADAN DI MAJELIS TAKLIM DARUSSALAM KUNIR
}

\author{
Ahmad Farihin, Septian Eka Prahardik, Ahmad Dasuki, Riema Afriani Kusumadewi, \\ Putri Anggraeni. \\ STAI Darussalam Kunir \\ STAI Darussalam Kunir \\ STAI Darussalam Kunir \\ STAI Darussalam Kunir \\ STAI Darussalam Kunir
}

Korespodensi: ahmadfarihin2789@gmail.com

\begin{abstract}
Old age is a period in which a person experiences changes in the dimensions he has; physical, psychological, spiritual, social, and potential dimensions. Ideally old age is filled with maturity that is stable at the changes experienced. However, the elderly will be faced with the problem of situational limitations both internally and externally. Following routine recitations is one of the activities that can cover the needs of solving problems in the elderly. This study uses a qualitative research method with a descriptive approach that seeks to explore in depth the motivation of the elderly in participating in routine recitation activities. Data collection techniques were carried out by intense interviews and direct field observations. The results of this study indicate that the motivation of the elderly to attend regular recitations is the fulfillment of learning and educational needs, the motivation of the elderly in attending routine recitations meets two aspects of motivation; component of values and components of hope, so it can be concluded that the elderly who are recitation participants are elderly who care about the future because they meet 4 of 5 indicators of elderly who care about the future. The supporting factors for the elderly in attending the recitation consist of internal and external factors. The level of motivation of the elderly in attending regular recitations is included in the category of inner motivation level (motivation that comes from inner strength) which is the highest level of motivation.
\end{abstract}

Keywords: learning motivation, elderly, physical, psychological, spiritual, social and potential dimensions

\begin{abstract}
ABSTRAK
Masa tua merupakan masa dimana seseorang mengalami perubahan pada dimensi-dimensi yang dimilikinya; dimensi fisik, psikologis, spiritual, sosial, dan potensi. Idealnya masa tua diisi dengan kematangan yang stabil pada perubahan dialami. Namun lansia akan dihadapkan dengan permasalahan keterbatsan keadaan baik dari internal maupun ekternal. Mengikuti pengajian rutin merupakan salah satu kegiatan yang dapat mencakup kebutuhan-kebutuhan dalam menyelesaikan masalah pada lansia. Penelitian ini menggunakan metode penelitian kualitatif dengan pendekatan deskriptif yang berusaha menggali secara mendalam mengenai motivasi lansia dalam mengikuti kegiatan pengajian rutin. Pengumpulan data menggunakan teknik wawancara secara intens serta observasi lapangan secara langsung. Hasil penelitian ini menjunjukkan bahwa motivasi lansia mengikuti pengajian rutin adalah pemenuhan kebutuhan belajar dan pendidikan, motivasi yang dimiliki lansia dalam mengikuti pengajian rutin memenuhi dua aspek motivasi; komponen nilai dan komponen harapan, sehingga dapat disimpulkan bahwa lansia peserta pengajian merupakan lansia yang peduli terhadap masa depan karena memenuhi 4 dari 5 indikator lansia yang peduli pada masa depan. Faktor pendukung lansia dalam mengikuti pengajian terdiri dari faktor internsik dan eksternsik. Tingkat motivasi lansia dalam mengikuti pengajian rutin termasuk dalam kategori level inner motivation (motivasi yang bersumber dari kekuatan dalam diri) yang mana merupakan tingkatan motivasi tertinggi.
\end{abstract}

Kata Kunci: motivasi belajar, lansia, dimensi fisik, psikologis, spiritual, sosial dan potensi 


\section{PENDAHULUAN}

A. Maslow menjelaskan hierarki piramida kebutuhan hidup pada manusia (human needs heierarky) memiliki 5 (lima) tingkatan kebutuhan, yaitu: 1) Basic needs, 2) Safety needs, 3) Psikhological needs, 4) Esteem needs, 5) Actualization needs (Abraham Maslow: 1943). Selanjtnya dari pendapat tersebut dapat dijelaskan bahwa kebutuhan dasar (basic needs) terbagi kedalam 3 (tiga) jenis kebutuhan, yakni: life needs (kebutuhan hidup), learning needs (kebutuhan belajar), dan education needs (kebutuhan pendidikan). Maka dari pernyataan tersebut dapat disimpulkan bahwa manusia tidak akan terlepas dari belajar dan pendidikan. Pada dasarnya pembelajaran seumur hidup (lifelong learning) menjadi suatu konsep pembelajaran yang bertujuan memenuhi jenis kebutuhan belajar (learning needs), dan juga kebutuhan pendidikan (education needs).

Senada dengan simpulan diatas, sebuah hadits nabi menegaskan dengan jelas bahwa pentingnya mencari ilmu itu tidak ada batas usia atau keadaan, dalam hadits tersebut dijelaskan bahwa menuntut ilmu harus dilakukan sepanjang hayat, sejak lahir hingga ajal menjemput. Nabi memerintahkan dengan jelas dalam sebuah riwayat;

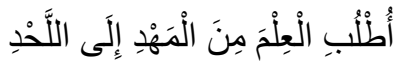

Artinya : "Tuntutlah ilmu itu sejak (masa) ayunan hingga masuk ke liang lahat".

Terlepas dari kualitas keshahihan hadits tersebut diatas, ajaran yang terkandung di dalamnya memberikan satu masukan serta motivasi yang sangat berharga bagi dunia pendidikan, disamping itu pula kandungan makna dari pesan di dalamnya tidak berseberangan dengan isi Al-Quran dan hadits-hadits mutawattir lainnya. Pendidikan luar sekolah non formal yang tidak dilembagakan secara resmi merupakan sebuah proses yang didapat seseorang dalam sehari-hari dengan sengaja atau tidak disengaja, umumnya tidak sistematis terjadi sejak seseorang lahir sampai akhir usianya.(Iswati, 2019)

Pendidikan sangat meiliki peran penting dalam meningkatkan kualitas sumberdaya. Oleh sebab itu, sejak tahun 1994 pemerintah telah penetapkan program wajib belajar pendidikan dasar semala sembilan tahun dengan ekspektasi semakin baik tingkat pendidikan akan semakin tinggi tingkat kesejahteraan. Selanjutnya program wajib belajar ini ditambahkan menjadi 12 tahun, hal ini sejalan dengan perkembangan jaman yang menuntut pendidikan dan skill yang semakin tinggi. Sejak tahun 2010 program wajib belajar mengalami perubahan penyebutan menjadi hak belajar, karena setiap warga negara memiliki hak yang sama dalam memperoleh pendidikan yang berkualitas, sesuai dengan apa yang diamanatkan pemerintah dalam UU No. 20 Tahun 2003 tentang Sistem Pendidikan Nasional.(Hakim, 2020)

Berdasar uraian di atas, tampak jelas bahwa Islam menaruh perhatian besar terhadap pendidikan sepanjang hayat atau seumur hidup. Namun pada kenyataannya pelaksanaan longlearn education kurang mendapatkan perhatian dari pemerintah, pemerintah hanya mewajibkan belajar selama 12 tahun. Sehingga penyelenggaraan hak pendidikan pada orang diatas usia wajib belajar, termasuk lansia, menjadi tanggung jawab swadaya masyarakat. Sehingga akses pelaksanaan pendidikan pada lansia terlaksana seadanya.

Oleh karena itu program-program pendidikan masyarakat secara luwes dilakukan penyesuaian untuk mengikuti perkembangan zaman dan trend kebutuhan belajar masyarakat.(Hoerniasih, 2019)

Terjadi fenomena pada masyarakat dewasa ini semangat mempelajari ilmu agama tidak hanya terbatas pada golongan usia tertentu saja, namun juga menyeluruh dari yang muda sampai yang lanjut usia. Di kampung maupun di kota penyelenggaraan pengajian rutin mingguan yang diikuti orang lanjut usia, misalnya, sangat mudah ditemukan.

Masyarakat di kampung Kunir dan sekitarnya, yang masuk golongan lanjut usia dan mengikuti kegiatan pengajian pada majelis taklim terbilang cukup banyak, hal ini dibuktikan dengan terselenggaranya beberapa ppengajian rutin, diatnataranya 1) Pengajian Rutin Mushalla 
Parapatan yang dieselenggarakan di Mushalla Al Rawi pimpinan Ustadzah Zaenab dan Ummi Khafsah, 2) Pengajian Rutin Masjid Ath-Thahiriyah Kunir pimpinan KH. Ghazali, dan 3) Pengajian Rutin Ahadan yang diselenggarakan di Majelis Taklim Darussalam Kunir pimpinan KH. Saefullah Hidayat.

Semua pengajian tersebut diselelnggarakan di kampung Kunir dengan hari yang berbeda dan pengelompokan peseta yang berbeda. Pengajian Rutin Mushalla Parapatan diikuti oleh ibu-ibu lanjut usia, Pengajian Masjid Ath-Thahiriyah diikuti oleh bapak-bapak lanjut usia, dan Pengajian Rutin Ahadan di Majelis Taklim Darussalam Kunir diikuti oleh lansia laki-laki dan perempuan.

Uraian diatas menunjukan betapa tinggginya animo dan antusiasme masyarakat golongan lanjut usia dalam mengikuti kegiatan pendidikan keagamaan. Sehingga peneliti tertarik unuk meneliti bagaimana motivasi belajar lansia dalam mengikuti pengajian rutin di Majelis Taklim Darussalam Kunir.

\section{TINJAUAN PUSTAKA}

Secara bahasa, Winardi (2002:1) mengemukakan kata motivasi (motivation) berasal dari bahasa Latin, yakni movere yang meiliki arti sesuatu yang menggerakkan (to move). Dan kata motivation adalah serapannya kedalam baha Inggris yang berarti pemberian motif, pemunculan motif atau hal yang melahirkan dorongan atau keadaan yang menimbulkan dorongan. Selanjutnya Winardi (2002:33) menjelaskan, motivasi seseorang bergantung kepada kekuatan motifnya. Berdasarkan paparan tersebut diskusi tentang motivasi tidak dapat lepas dari konsep motif. Pada dasarnya dapat dikatakan bahwa motif adalah penyebab terjadinya tindakan. Dalyono (2005: 55) juga menjelaskan, "Motivasi merupakan daya pendorong/ penggerak untuk melakukan suatu pekerjaan, yang bisa berasal dari dalam diri sesorang atau juga dari luar".

Menurut Pintrich motivasi belajar bisa dimaknai sebagai upaya dalam memunculkan usaha yang lebih, selama pembelajaran berlangsung dan menggunakan strategi yang bisa menunjang proses belajar seperti perencanaan, ppengaturan dan pelatihan soal-soal pada materi pelajaran, meninjau tingkat pemahaman sebuah materi, serta menghubungkan materi baru dengan ilmu pengetahuan yang sudah pernah dikuasai.(Putri \& Soetjiningsih, 2018)

\subsection{Peran dan Fungsi Motivasi}

Hamzah Uno (2013:27-29) menuturkan motivasi dalam belajar memppunyai peran sebagai penentu dalam penguatan belajar, memperjelas tujuan belajar serta menentukan ketekunan dalam belajar. Hamalik (2011: 108), menjelaskan fungsi motivasi meliputi tiga hal; Pertama, sebagai pendorong lahirnya suatu perbuatan/kelakuan. Kedua, motivasi dapat berfungsi sebagai pemberi arah, maksudnya mengarahkan perbuatan pada pencapaian tujuan yang dimaksudkan. Ketiga, motivasi juga dapat berfungsi sebagai daya penggerak, artinya sebagai motor penggerak dalam belajar.

Dari uraian diatas dapat disimpulkan bahwa motivasi memiliki fungsi sebagai pendorong, pengarah serta penggerak suatu perbuatan.

\subsection{Aspek Motivasi Belajar}

Printich dan Groot (1990) menjelaskan (dalam Putri \& Soetjiningsih, 2018) mengenai aspek-aspek motivasi dalam belajar menurut yaitu:

a. Value Component (komponen nilai)

Komponen nilai ini menyangkut persepsi peserta didik tentang alasan apa sehingga dia terlibat dalam kegiatan pembelajaran, seperti alasan tantangan, rasa penasaran, penguasaan, nilai, penghargaan, kinerja, penilaian oleh orang lain, dan kompetisi, dan 
seberapa menarik, penting, dan berguna pekerjaan dalam pembelajaran dikerjakan (task value)

b. Expentancy Component (komponen harapan)

Komponen harapan mengarah pada keyakinan peserta didik bahwa usaha mereka dalam belajar akan mampu menghasilkan sebuah hasil yang positif. Ada 2 (dua) bagian komponen harapan ini,:Pertama, Control of learning belief, yaitu keyakinan akan hasil belajar bergantung pada upaya diri sendiri, akan berbeda dengan faktor eksternal seperti guru. Jika peserta didik percaya bahwa usaha mereka dapat perbedaan pada pembelajaran, maka mereka akan belajar lebih giat menggunakan strategi yang dianggap lebih efektif; dan kedua, Self efficacyfor learning and performance, yakni penilaian tentang kemampuan diri sendiri dalam menyelesaikan tugas serta kepercayaan pada keterampilan untuk melakukan tugas tersebut.

c. Affective Component (komponen afeksi)

Komponen afektif ini dapat diibaratkan dengan kata "Apa yang saya rasakan terhadap tugas ini?". Jadi pertanyaan itu dapat menimbulkan reaksi seperti cemas, marah, sedih, dan atau bangga. Komponen afeksi dapat dilihat melalui uji kecemasan (test anxiety). Test Anxiety, mempunyai dua komponen, yaitu kekhawatiran atau komponen kognitif, dan komponen emosionalitas. Komponen kekhawatiran mengacu pada pikiran negatif peserta didik yang dapat mengganggu kinerja, sedangkan komponen emosionalitas mengarah pada aspek gairah afektif dan fisiologis kecemasan.

\subsection{Tingkatan Motivasi}

Akhmad Farhan (2015) mengungkapkan bahwa motivasi mempunyai tingkatan. Tingkatan pertama adalah tingkat dasar, kedua tingkat motivasi menengah dan ketiga motivasi tingkat tinggi. Semakin tinggi tingkatan motivasi seseorang akan semakin baik karena akan meningkatkan upayanya dalam meraih sesuatu yang diinginkan.

Tingkatan motivasi yang paling dasar ialah motivasi yang berdasarkan pada rasa ketakutan (fear motivation). Seseorang yang didorong oleh motivasi ini akan melakukan sesuatu karena takut. Misalnya, jika tidak dilakukan maka sesuatu yang buruk akan menimpanya. Contohnya orang patuh pada atasa karena takut dipecat, seorang anak belajar karena takut dimarahi orang tua. Pada tingkatan motivasi ini, mereka melakukan sesuatu bukan berdasarkan kesadaran dan ingin mencapai tujuan tertentu tapi lebih dikarenakan oleh keterpaksaan atau untuk "menggugurkan kewajiban" semata.

Motivasi tingkat kedua adalah dorongan untuk mencapai sesuatu (achievement motivation). Motivasi ini lebih baik dari motivasi yang bersumber dari ketakutan, sebab sudah ada tujuan tertentu. Seseorang melakukan sesuatu karena ingin mencapai suatu sasaran atau prestasi tertentu.

Terakhir motivasi ketiga adalah motivasi yang didorong oleh kekuatan dari dalam diri seseorang (inner motivation), yaitu didasarkan pada misi atau tujuan hidupnya. Seseorang yang memiliki misi yang jelas dalam hidupnya bekerja berdasarkan nilai (values) yang ia yakini kebenarannya. Nilai-nilai itu dapat berupa rasa cinta (love) pada sesama atau ingin memiliki makna dalam menjalani hidupnya.

\subsection{Majelis Taklim dan Pengajian}

Majlis taklim adalah sekumpulan kegiatan pengajian, sehingga motifnya adalah mencari ilmu agama dan mendapatkan ganjaran dari Allah, sehingga pesertanya semakin berkembang pesat di berbagai daerah (Rifa'i, 2019). Lebih lanjut Zakiyah Darajat (dalam Rifa'i: 2019) mengemukakan bahwa majelis taklim adalah salah satu model pendidikan non formal yang diharapkan bisa berkembang bersama dengan lembaga pendidikan lainnya. Model pembinaan di majelis taklim diharapkan dapat menawarkan sebuah solusi dari permasalahan yang dihadapi umat di antaranya berupa tantangan akibat kemajuan teknologi, dan masalah- 
masalah pada hubungan sosial masyarakat seperti pembinaan keluarga dan masalah pendidikan anak. Posisi majelis taklim yang cukup strategis karena berdiri sejajar dengan lembaga pendidikan lainnya seperti sekolah, madrasah atau pesantren menempatkan dirinya mengakar di kehidupan masyarakat. Sehingga peranannya sangat penting sebagai sarana pembinaan umat (Rifa'i, 2019).

\subsection{Kategori Lansia}

Lansia atau orang lanjut usia adalah seseorang yang mencapai usia lebih dari atau sama dengan 55 tahun (WHO, 2013). Lebih lanjut WHO membagi lansia kedalam 5 (lima) kelompok usia yaitu: 1) Usia pertengahan (middle age), yaitu kelompok usia 45-54 tahun. 2) Lansia (elderly), yaitu kelompok usia 55-65 tahun. 3) Lansia muda (young old), yaitu kelompok usia 66-74 tahun. 4) Lansia tua (old), yaitu kelompok usia 75-90 tahun.

Beberapa permasalahan umum yang dialami lansia, antara lain: keadaan fisik yang melemah dan tidak berdaya, status ekonomi terancam, perlu menentukan kondisi hidup sesuai perubahan status ekonomi dan kondisi fisik, perlu mencari teman baru untuk menggantikan suami/isteri yang telah meninggal atau pergi jauh atau cacat, perlu mengembangkan kegiatan baru untuk mengisi waktu luang, perlu belajar memperlakukan anak yang sudah besar sebagai orang dewasa, mulai terlibat dalam kegiatan masyarakat, mulai merasakan kebahagiaan dari kegiatan yang sesuai untuk lansia, dan menjadi korban kriminalitas (Ismayadi, 2004)

Nurul Khotimah (2017) menuturkan bahwa indikator lansia yang memiliki kepedulian terhadap masa depan adalah lansia yang memperhatikan akan kualitas pada (5) lima jenis dimensi, yakni; dimensi fisik, dimensi psikologis, dimensi mental dan spiritual, dimensi sosial kemasyarakatan, dan dimensi pengembangan potensi (Khotimah et al., 2017)

\section{METODE}

Penelitian ini merupakan penelitian lapangan (field research) dengan menggunakan pendekatan kualitatif deskriptif. Sukmadinata menjelaskan penelitian dengan pendekatan kualitatif adalah penelitian yang ditujukan untuk mendeskripsikan dan menganalisis terhadap fenomena, aktivitas sosial, peristiwa, kepercayaan, sikap, persepsi, pemikiran orang secara individual maupun kelompok (Sukmadinata: 2014:60). Pendekatan kualitatif merupakan pendekatan yang dilakukan untuk memahami fenomena yang dialami oleh subjek penelitian secara holistik dan data yang diperoleh dideskripsikan dalam bentuk deskripsi kata-kata (Moeloeng: 2014:6). Penelitian ini menarik interpretasi dan menggambarkan data dan informasi yang diperoleh dalam menjawab permasalahan pada penelitian yang dilakukan di Majelis Taklim Darussalam Kunir, Kampung Kunir Desa Simpar Cipunagara-Subang yang menyelenggarakan Pengajian Rutin Ahadan. Ahadan berasal dari kata Ahad yang berarti hari Minggu, penyebutan ini karena pelaksanaan pengajian ini dilakukan setiap hari Minggu.

Penelitian menetapkan rumusan masalah sebagai berikut; 1) Apa motivasi lansia mengikuti pengajian rutin Ahadan di Majelis Taklim Darussalam Kunir?; 2) Faktor apa saja yang mendukung lansia dalam mengikuti pengajian rutin Ahadan di Majels Taklim Darussalam Kunir; 3) Bagaimana motivasi lansia dalam mengikuti pengajian rutin Ahadan di Majelis Taklim Darussalam Kunir?.

Teknik pengumpulan data pada penelitian ini menggunakan wawancara, observasi, dan strudi dokumentasi. Pengumpulan data menggunakan wawancara secara mendalam dilakukan berkali-kali dan intens sehingga diperoleh jawaban yang relevan terkait masalah penelitian Observasi dengan melakukan pengamatan dengan turun langsung ke lapangan.. Selanjutnya studi dokementasi, yakni penggalian data berupa dokumen tertulis yang tersimpan dalam bentuk buku, Undang-Undang, Peraturan Pemerintah, internet, dan lain sebagainya yang mendukung informasi yang diperlukan pada penelitian ini. 
Sedangkan informan pada penelitian ini terdiri dari peserta lansia pengajian pada Majelis Taklim Darussalam Kunir. Sedangkan informan pendukung terdiri dari pimpinan majelis taklim, pembantu pimpinan mejelis taklim, dan beberapa keluarga peserta pengajian.

\section{HASIL DAN PEMBAHASAN}

\subsection{Motivasi Lansia Mengikuti Pengajian Rutin Ahadan di Majelis Taklim Darussalam Kunir}

Dari olah data berupa hasil wawancara diperoleh bahwa motivasi lansi mengikuti pengajian Ahadan di Majelis Taklim Darussalam Kunir meliputi; 1) Pemenuhan kebutuhan terhadap mengisi kekosongan waktu, 2) Menjalankan anjuran Nabi SAW tentang menuntut ilmu sampai akhir hayat, 3) Mendapatkan interaksi sosial dengan sesama, 4) Mendapatkan amalan-amalan berupa dzikir dan doa-doa, 5) Berharap mendapatkan pahala menuntut ilmu. Hal ini sebagaimana ditegaskan oleh hasil wawancara Bersama Ibu Hj. Masitoh (65 tahun): "Ah, Jang. Emak mah itung-itung ngeusi waktos, weh. Jeung deui apan pami ngaos mah pendak jeung batur, insyaallah kenging pahala, kenging amalan-amalan sareng doa-doa ti Pa Kiai" ("Ah, nak. Emak mah hitung-hitung mengisi waktu kosong saja. Dan juga jika mengikuti pengajian akan bertemu dengan teman, insya Allah akan mendapat pahala, mendapat amalan dan doa-doa dari Pak Kiai")

Dari temuan diatas dapat dipahami bahwa motivasi lansia mengikuti pengajian rutin merupakan sebuah upaya dalam pemenuhan kebutuhan dasar (basic needs) berupa kebutuhan belajar (learning needs) serta kebutuhan pendidikan (education needs) sesuai dengan teori hirarki kebutuhan Abraham Maslow (A. Maslow: 1943).

Dilihat dari aspeknya (Printich dan Groot: 1990), motivasi yang dimiliki lansia dalam mengikuti pengajian rutin ini memenuhi setidaknya 2 (dua) aspek; 1) value component (komponen nilai) yaitu komponen nilai yang menyangkut lansia peserta pengajian memiliki persepsi tentang alasan mengapa mereka terlibat didlam kegiatan pengajian seperti alasan tantangan, rasa penasaran, penguasaan, nilai, penghargaan, kinerja, penilaian oleh orang lain, dan kompetisi, dan seberapa menarik, penting, dan berguna pekerjaan dalam pembelajaran dikerjakan (task value); dan 2) expentancy component (komponen harapan) yaitu komponen harapan yang mengarah pada keyakinan lansia peserta pengajian bahwa usaha mereka untuk belajar akan mendapatkan hasil yang positif dan berguna.

Sejalan dengan penuturan diatas, lansia yang aktif mengikuti pengajian rutin memenuhi sebagaian besar indikator sebagai lansia yang peduli terhadap masa depan sebagaimana yang dituturkan oleh Nurul Khotimah, yakni indikator lansia yang memiliki kepedulian terhadap masa depan adalah lansia yang memperhatikan akan kualitas pada (5) lima dimensi, yakni; dimensi fisik, dimensi psikologis, dimensi mental spiritual, dimensi sosial kemasyarakatan, dan dimensi pengembangan potensi (Khotimah et al., 2017). Hanya pada dimensi fisik yang tidak tercakup dalam kegiatan pengajian rutin.

\subsection{Faktor Pendukung Pada Lansi dalam Mengikuti Pengajian Rutin Ahadan di Majelis Taklim Darussalam Kunir}

Dari hasil wawancara dengan Bapak Narli (63 Tahun) diperoleh keterangan bahwa dirinya suka dengan gaya penyampaian pengisi pengajian karena selain menggunakan bahasa yang sederhana dan mudah dimengerti, juga banyak diselingi joke atau dongeng yang mengandung hikmah. Dari hasil wawancara dengan pimpinan majelis taklim diperoleh keterangan bahwa pengantar pengajian menggunakan Bahasa Sunda, hal ini dikarenakan mayortitas peserta pengajian adalah orang Sunda. Materi pengajianpun disuguhkan dengan cara tematik.

Peneliti melakukan observasi dengan mengikuti kegiatan pengajian secara langsung, ditemukan bahwa suasana pengajian sangat kondusif. Penggunaan soundsyistem yang memadai, tempat yang nyaman, penempatan jamaah berdasarakan jenis kelamin dan suguhan 
alakadarnya juga turut menambah suasana kekluargaan dan mendukung kenyamanan peserta pengajian.

Temuan-temuan diatas mendukung apa yang telah dikemukakan oleh Hamalik bahwa factor pendukung pemebelajaran terbagi menjadi 4 (empat) bagian; 1) Faktor yang berasal pada diri sendiri (faktor intern); 2) Faktor yang berasal dari lingkungan sekolah; 3) Faktor yang bersumber dari lingkungan keluarga; 4) Faktor yang bersumber dari lingkungan masyarakat.

Berdasarkan paparan diatas dapat disimpulkan bahwa faktor pendukung pada lansia peserta pengajian rutin meliputi; 1) faktor intern; 2) faktor dari fasilitas pada kegiatan pengajjian yang disediakan oleh penyelenggara; dan 3) faktor lingkungan keluarga dan masyarakat yang mendukung.

\subsection{Tingkat Motivasi Lansia dalam Mengikuti Pengajian Rutin Ahadan di Majelis Taklim Darussalam Kunir}

Motivasi pada hakikatnya dapat membantu memahami dan menjelaskan perilaku individu, termasuk perilaku individu yang sedang belajar. Sehingga dimanapun individu belajar, motivasi memberikan banyak kontribusi pada perilakunya termasuk juga di sekolah (Pranowo, 2019).

Dari hasil wawancara dengan pimpinan majelis taklim peneliti mendapatkan keterangan frekuensi kehadiran peserta pengajian setiap minggunya cenderung stabil. Kecuali jika bertepatan dengan musim panen raya, pengajian sengaja diliburkan karena banyak yang tidak hadir. Dari fakta tersebut dapat ditarik kesimpulan bahwa tingkat motivasi lansia dalam mengikuti pengajian rutin Ahadan di Majelis Taklim Darussalam Kunir tergolong pada tingkatan motivasi pada level tertinggi yakni inner motivation.

Sebagaimana dikemukakan oleh Akhmad Farhan bahwa tingkatan motivasi memiliki 3 (tiga) tingkatan; 1) fear motivation, motivasi yang berasal dari ketakutan; 2) achievement motivation, motivasi yang berasal dari keinginan untuk mendapatkan sesuatu; 3) inner motivation, motivasi yang berasal dari kekuatan diri. Tingkatan tertinggi adalah inner motivation yaitu motivasi yang didorong oleh kekuatan dari dalam karena didasarkan oleh misi atau tujuan hidup. Seseorang yang telah menemukan misi hidupnya bekerja berdasarkan nilai (values) yang diyakini kebenarannya.

\section{KESIMPULAN}

Berdasarkan hasil penelitian yang telah dilaksanakan di Majelis Taklim Darussalam Kunir diperoleh kesimpulan dapat diketahui bahwa hasil penelitian menunjukkan motivasi lansia mengikuti pengajian rutin merupakan sebuah upaya dalam pemenuhan kebutuhan dasar (basic needs) berupa kebutuhan belajar (learning needs) dan kebutuhan Pendidikan (education needs. Motivasi yang dimiliki lansia dalam mengikuti pengajian rutin ini memenuhi setidaknya 2 (dua) aspek; 1) value component (komponen nilai), dan 2) expentancy component (komponen harapan). Dapat simpulkan pula bahwa lansia yang mengikuti pengajian rutin memenuhi 4 (empat) dari 5 (lima) indikator sebagai lansia yang peduli terhadap masa depan, yakni; dimensi fisik, dimensi psikologis, dimensi mental spiritual, dimensi sosial kemasyarakatan, dan dimensi pengembangan potensi.

Faktor pendukung pada lansia dalam mengikuti pengajian rutin Ahadan di Majelis Taklim Darussalam Kunir meliputi; 1) faktor intern berupa keinginan yang kuat dari dalam diri mereka; 2) faktor ekstern berupa fasilitas pada kegiatan pengajjian yang disediakan oleh penyelenggara dan lingkungan keluarga serta masyarakat yang mendukung.

Tingkat motivasi pada lansia dalam mengikuti pengajian rutin Ahadan di Majelis Taklim Darussalam Kunir mencapai pada tingkat inner motivation dimana tingkatan tersebut merupakan tingkat motivasi tinggi dan meiliki sifat dorongan yang tanpa paksaan, melalukakn dengan sukarela dan tanpa takut apapun sebagaimana yang ada pada karakter fear motivation. 
Sehingga ketika ada faktor lain yang membuat pengajian diliburkan seperti saat musim panen tiba, hal tersebut tidak membuat para jamaah menjadi sulit. Mereka membuat kesepakatan dengan pimpinan majelis taklim untuk meliburkan pengajian, kemudian setelah panen usai pengajian dilanjutkan kembali.

\section{DAFTAR PUSTAKA}

Dalyono. (2005). Psikologi Pendidikan, Jakarta: PT. Rineka Cipta

Darmojo, Boedhi. 2015. Buku Ajar Geriatri (Ilmu Kesehatan Usia Lanjut). Jakarta: FKUI

Farhan, Akhmad. 2015. https://www.kompasiana.com/akhmadfarhan/550063668133116619fa76ad/tingkatanmotivasi

Hamalik, Oemar. 2011. Proses Belajar Mengajar. Jakarta. PT Bumi Aksara.

Hamalik, Oemar. 1983. Metode Belajar dan Kesulitan-kesulitan Belajar, Edisi ke2, Bandung: Penerbit Tarsito.

Hamzah B. Uno. (2013). Teori Motivasi dan Pengukurannya. Jakarta: Bumi Aksara.

Hakim, A. (2020). FAKTOR PENYEBAB ANAK PUTUS SEKOLAH. Jurnal Pendidikan, 21(2), 122-132. https://doi.org/10.33830/jp.v21i2.907.2020

Hoerniasih, N. (2019). Lifelong Learning Dalam Pemberdayaan Masyarakat Untuk Kemandirian Berwirausaha. Indonesian Journal Of Adult and Community Aducation, 1(1), 31-39.

Iswati. (2019). LONG LIFE EDUCTION DALAM PERSPEKTIF HADITS (Suatu Tinjauan Pendidikan Sejak Pranatal dan Analisis Terhadap Kualitas Hadits Pendidikan Sepanjang Hayat). At-Tajdid, 3(02), 126-147.

Khotimah, N., Gunardo, G., Ghufron, A., Sugiharti, S., \& Aryekti, K. (2017). LANJUT USIA (LANSIA) PEDULI MASA DEPAN DI DAERAH ISTIMEWA YOGYAKARTA. Geomedia: Majalah Ilmiah Dan Informasi Kegeografian, 14(2). https://doi.org/10.21831/gm.v14i2.13815

Pranowo, T. A. (2019). Analisis Tingkat Motivasi Belajar Siswa di MI Ma'arif Grabag Magelang Jawa Tengah. Indonesian Journal of Guidance and Counseling: Theory and Application, 8(2). https://doi.org/10.15294/ijgc.v8i2.31166

Putri, C. gustian, \& Soetjiningsih, C. H. (2018). Hubungan Antara Dukungan Sosial Keluarga Dengan Motivasi Belajar Pada Remaja Yang Orang Tuanya Bercerai. Jurnal Mitra Pendidikan, 5(3), 644-656.

Rifa'i, M. K. (2019). Pengelolaan Majlis Taklim Dan Pengajian Umum. Ibriez : Jurnal Kependidikan Dasar Islam Berbasis Sains, 4(1). https://doi.org/10.21154/ibriez.v4i1.60

Syaodih Sukmadinata, Nana. 2014. "Metode Penelitian Pendidikan". Bandung: PT Remaja Rosdakarya.

Winardi. (2002). Motivasi dan Pemotivasian dalam Manajemen. Jakarta: PT Raja Grafindo Persada 